\title{
The tectonic evolution and hydrocarbon potential in the boundaries of Vietnam continental shelf
}

- Huy Tran Nhu

- San Ngo Thuong

- Binh Kieu Nguyen

- Xuan Tran Van

- Kha Nguyen Xuan

- Huy Nguyen Xuan

- Tuan Nguyen Van

University of Technology,VNU-HCM- tvxuan@hcmut.edu.vn

(Manuscript Received on August 20 ${ }^{\text {th }}, 2014$; Manuscript Revised November 11 ${ }^{\text {th }}$, 2014)

\section{ABSTRACT:}

Recent survey results indicate the presence of Tertiary sedimentary basins with hydrocarbon potential in the boundaries of Vietnam continental shelf. These basins were perhaps formed in the Early Oligocene on the Mesozoic basement of continental crust and were filled with mainly deltaic clastic sediments. From very early Miocene these basins have linked together and became wider. Sediments of marine and prograding delta facies accumulated and widespreaded on the whole continental shelf. At the Middle Miocene to present-day the opening of the Bien Dong Sea (Vietnam East Sea), the regional tectonic subsidence and the eustatic fluctuation had

Keyword: Boundaries of continental shelf, prograding, retrograding, petroleum system, potential play, gas hydrate.

\section{INTRODUCTION}

Boundary of Vietnam continental shelf exist the Tertiary sediment basins in which the oil and gas potential proved through exploration and production results. The basins recognized generate from early Oligocene above continental foundation with Mesozoic age content deltaic clastic facies. At begin of Miocene the basins have been extent, correlated together with created sedimentary formations of open and deep marine facies with turbidite shale, platform carbonate including reef build-up. Andesite and basalt extrusion occurred in form of dykes resulting from tectonic inversions in Late Oligocene, in the beginning of Middle Miocene, particularly in Late Miocene-Pliocene.

These Tertiary sedimentary basins are expected to have hydrocarbon potential and need to be investigated and explorated adequately. The main risk is the drilling technology, the exploitation in the deep sea and high investment cost. prominent marine and prograding delta facies covered throughout continental shelf. Since Middle Miocene up to recent, associated with the extension of Eastern Sea, the subsidence of region and sea level variation raised the favorable conditions to develop open sea and deep water settings in which mostly content turbidite shale and terrace carbonate intermix with reef build-up. The andesit and basaltic extrusive may generate in dyke

\section{Trang 26}


form and surface layers which related to tectonic reversed activities at the late Oligocene and early Middle Miocene and especially at the end of MiocenePliocene.

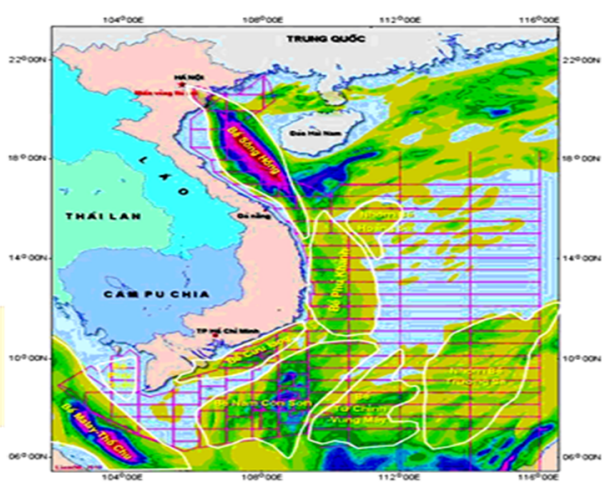

Figure 01. Distribution sketch of oil and gas

\section{The tectonic evolution history}

The open sea and deep water regions of Vietnam continental shelf include areas of Bien Dong sea surrounding basins such as PhuKhanh basin, Eastern shelf of Nam Con Son basin, and Tu Chinh-Vung May basin group (figure 01). These basins been generated and developed in structural geology region complicatetly, the vestiges of micro Mezozoic Indosinia plate which partly oceanismed during Bien Dong Sea widespreaded, happened mostly in Oligocene. These basins to be considered rift basins, which formed synthetic with rift and back-arc basins in South-East Asia (SEA), have similar development stages.

The convolution history of these basins include three main stages (fig 02, 03) [2]:

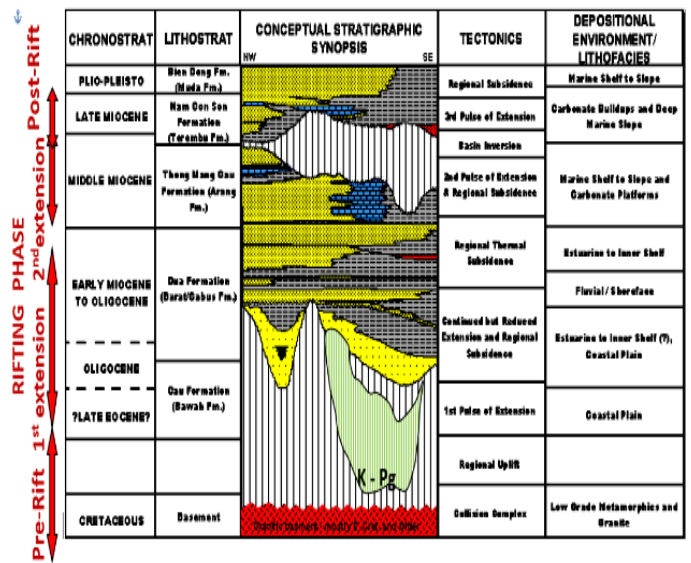

Figure 02. The evolution model of tectonic-facies Tertiary rift basin in boundaries of Vietnam continental shelf.

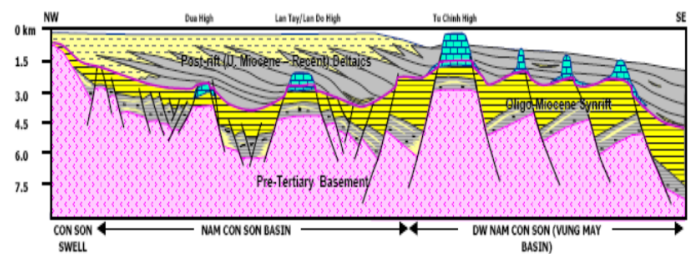

Figure 03. The cross section of generation and evolution model in boundaries of continental shelf sedimentary basins

Pre rift stage Creta-Paleogene (145-60 Ma) (figure 04).

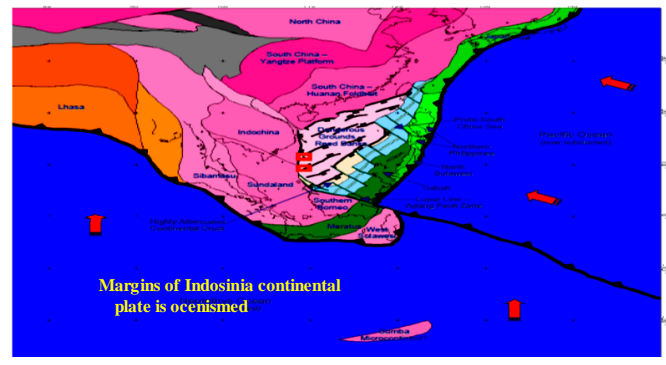

Figure 04. The tectonic evolution history of SEA, prerift stage (145-60 Ma) [1]

Syn rift stage early Eocene-Miocene (55-15 Ma) (figures 05, 06).

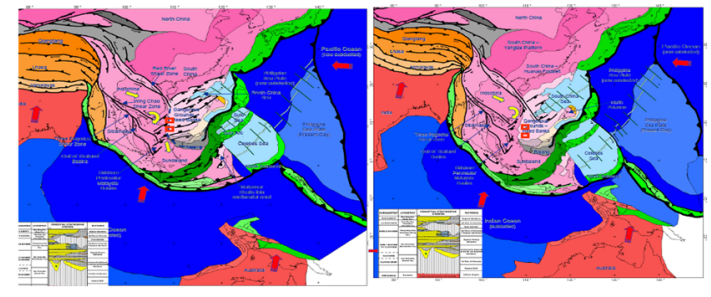

Figure 05. SEA tectonic convolution model of syn rift stage Early Eocene-Late Oligocene 43.5-23 Ma (left) and Oligocene-Early Miocene 23-21 Ma (right).
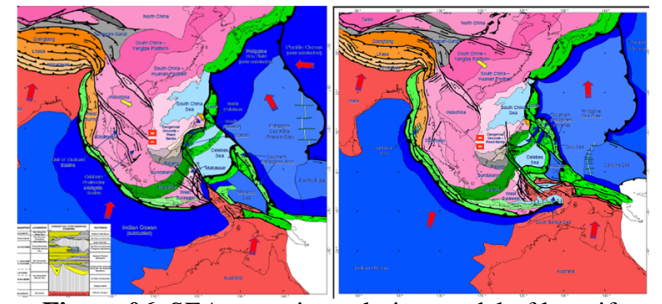

Figure 06. SEA tectonic evolution model of late rift stage Middle-Late Miocene 13-7.2 Ma (left) and post rift stage Late Miocene-Pliocene $\sim 6.8 \mathrm{Ma}$ (right).

Post rift stage Late Miocene -Pliocene -Quarterly (after 7.2 Ma) (figure 07). 


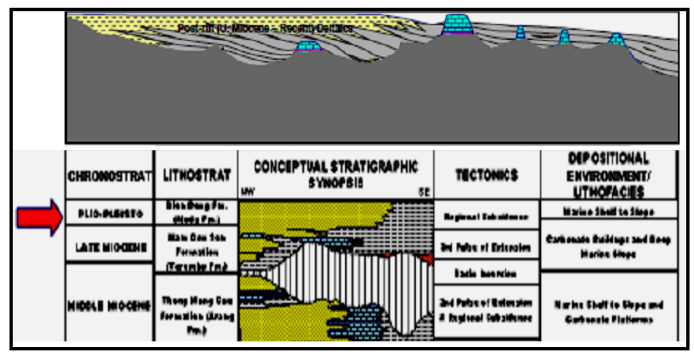

Figure 07. The evolution in the boundaries of continental shelf sedimentary basins in post rift stage Late Miocene-

$$
\text { Pliocene. }
$$

Petroleum system in boundaries of continental shelf sedimentary basins.

In rift basins of continental shelf boundaries belong to deep water, fared edge have not any petroleum exploration wells. The commercial hydrocarbon just discovery in shallow shelf with the depth $<500 \mathrm{~m}$ sea level, such as Phu Khanh basin, Nam Con Son basin in coral build up, clastic with ages of middle and lower Miocene. Based on seismic results and correlate with blocks which had the exploration well data could build up the petroleum system point of view for the offshore region (fig 08).

The Source Rock: The seismic interpretation results and tectonic evolution presented that the deep water and fared edge have the similar evolution history in the whole basin. The Paleogene and Miocene basins were buried by subsidiary thermo shrinkage in late Miocene and Pliocene-Plesitocene. The shale lacustrine sediment with abundant of organic matters and coal matter aged Oligocene as well shale of flooding plain are concerned of source rocks with have potential to generate hydrocarbon for deep water and fared edge regions at Phu Khanh, Nam Con Son and Tư Chính Vũng Mây basins as well. The deep buries with fast subsidiary velocity of this source rock accelerate the maturation degree of organic materials and expelled the oil and gas out of the source rocks. The results of geochemistry modeling built up in Phu Khanh and Nam Con Son basins presented the organic materials those accumulated in syn rift stage is falling in oil windows. The hydrocarbon expellee is continuously in Quarterly. The thick shale settings have 200-300 m thickness and distributed at $600-800 \mathrm{~m}$ deep are also determined have gas hydrate generating potential.

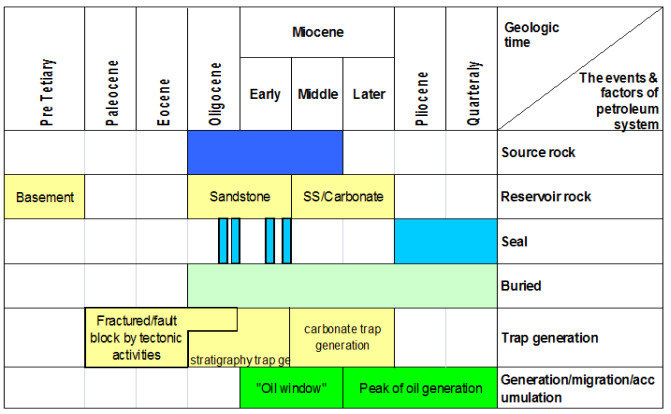

Figure 08. The sketch of petroleum system in deep water and fared edge sedimentary basins [2]

The Reservoir: Quite popularly with all Tertiary rift basins in Vietnam continental shelf, the reservoir rocks are pre-Tertiary fractured basement reservoirs, especially fractured Mesozoic granitoid blocks. The analysis results of basin sediment environment evolution performed the ability to generate the alluvial channel, alluvial fans and delta transmit sand, bars. The Oligocene and Miocene turbidite and carbonate reservoir in Middle-late Miocene coral built up formation are potential reservoirs as well.

The Seal: The cap rocks are regionally and locally in Oligocene-early Miocene shale formation and especially in thick deep water shale of PliocenePleistocene. The faults also take the role as seal and to constrain the migration of oil and gas in structural traps.

The Trap: Most common are structural traps in such uplift block of basement, folds, usually associated with faults. These trap generated in inversed tectonic at the end of Oligocene -early Miocene (?) and Middle-later Miocene. Moreover, the coral build-up forms of aged Middle-early Miocene are important potential aspects as well. The stratigraphy and pinchout at the flank of folds are also need to concern discovery.

Point of view to petroleum play in boundaries of Vietnam continental shelf (figure 09)

At these Tertiary sedimentary basins in deepwater and marginal of Vietnam continental shelf perhaps existent the following hydrocarbon plays:

- $\quad$ Raised block play of pre-Tertiary fractured basement;

- Elevated-fault play of clastic sediments in syn-rift Oligocene- early Miocene;

\section{Trang D8}


- Build-up play of coral blocks, Middle-early Miocene carbonate form;

- Play turbidite Pliocene- early Pleistocene.

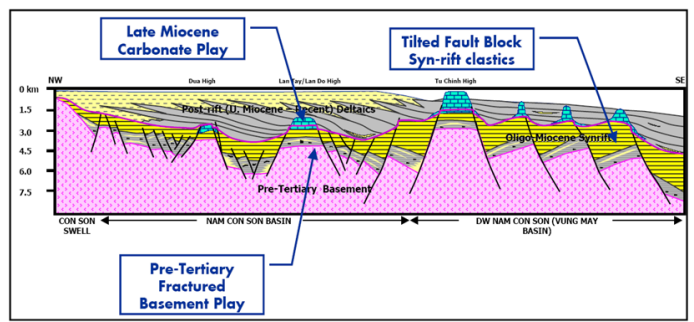

Figure 09. The distribution of hydrocarbon traps.

Play of pre-Tertiary elevated fractured basement block. (figure 10)



Figure 10. The point of view to petroleum play pre-Tertiary elevated fractured basement.

The Source rock: The Oligocene lacustrine thickness shale and shale coal generated in late rift covered on fractured basement.

The Reservoirs: Mostly Mesozoic (Jura, Kreta) granitoid rocks and Mesozoic-Paleozoic metamorphism, moreover may be Carbon-Permi fractured carbonate.

The Seal: Lacustrine shale facies in Oligocene syn rift, which generated the thickness cap throughout the region, the potential seal on pre-Tertiary elevated fractured basement.

The Trap: The buried raised blocks and elevated blocks with twisted and compressed along faults.

\section{Built up carbonate and reef play (figure 11)}

The Source rocks: The abundant organic material shale, the Oligocene lacustrine coal shale, the shale of late Miocene seashore flood plain, the fared edge submarine fan;
The Reservoirs: Bio-carbonate, coral, karstic carbonate, dolomized carbonate aged of Middle-late Miocene.

The Seal: Shaly thickness cap in open sea, deep water, shale in rear of submarine fan of PliocenePleistocene sedimentary settings.

The Trap: The built up carbonate with cap and wisp form, the reef, the dune of leaf-cuticle waxes aged Miocene, mainly middle-upper Miocene;

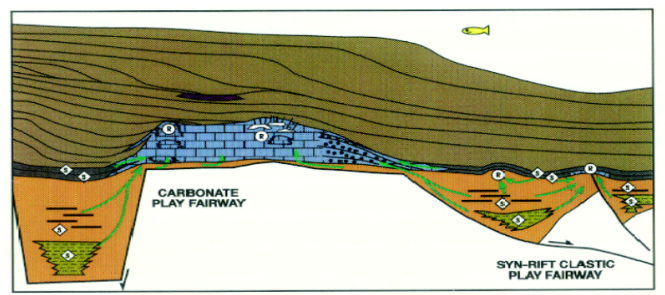

Figure 11. The point of view to lower-middle Miocene carbonate play.

Elevated-fault play (figure 12)

The Source rocks: The Oligocene thickness coalmud with lacustrine facies and Miocene marine shale abundant of organic materials.

The Reservoirs: The interbed sandstone in the Oligocene- early Miocene, syn-ryft clastic formation.

The Seal: The shale with restrict, locally distribution in Oligocene syn-ryft clastic formation, the moderate shale layers in early Miocene coastal sedimentary settings, the potential cap are also thickness marine shale of deep water settings in post-rift early Miocene-Pliocene. The faults not only take the role of migration path but also prevent the migration of oil and gas.

The Trap: The elevated blocks divided by sealed faults.

\section{Turbidite play (Figure 13)}

The Source rocks: The shale stratum in which abundant organic materials interbed in to turbidite formation.

The Reservoirs: The sandy lens and thin layers interbed in to turbidite formation, sub marine fan and submarine channels. 
The Seal: The shaly stratum with sub marine fan and deep water facies, interbed in to Pliocene and early Pleistocene turbidite formation.

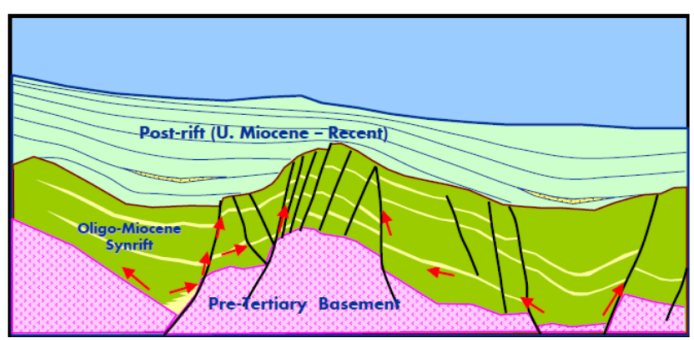

Figure 12. The point of view to elevated-fault block in rift generation Oligocene-Early Miocene play

The Trap: Normally are thin lens, multi- layers, fold and stratigraphy traps in prograding wedges.

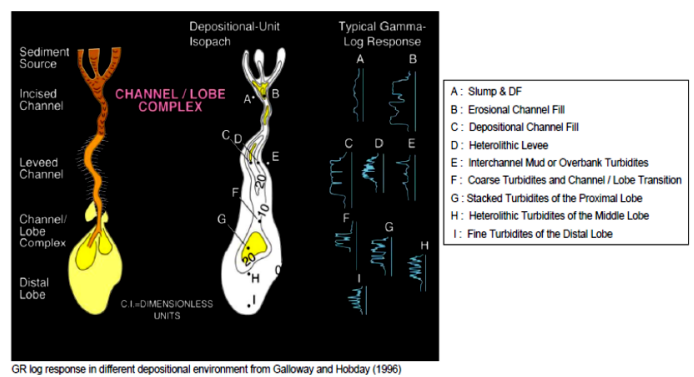

Figure 13. The distribution model of turbidite formation at sub marine fans [3]

\section{CONCLUSIONS AND RECOMMENDATION}

The survey results in margins of Vietnam continental shelf indicated, from geologic structure point of view, they are suture zone to deep sea area of Phu Khanh, Nam Con Son basins and develop the Tu Chinh-Vung May basin group. These basins were formed in the Late Eocene-Early Oligocene on the
Mesozoic basement of continental crust and were filled with mainly clastic lacustrine, deltaic intermix with coastal sediments. Since Miocene, these basins have become extent and linked together with apparently sediments of marine and prograding delta facies accumulated and widespreaded on the whole continental shelf. At the Middle Miocene to present-day with the opening of the Bien Dong Sea, the regional tectonic subsidence and the eustatic fluctuation had created sedimentary formations of open and deep marine facies with turbidite shale, stacked sandstone. The rapid rate of deposition in the early MiocenePliocene accelerated the mature range of organic materials and the hydrocarbon expulsion at the beginning of early Miocene to the present-day. The organic material range is determined at the principle zone of oil and gas generation. The oil and gas potential plays determined here after: (1) Raised block play of pre-Tertiary fractured basement; (2) Elevated-fault play of clastic sediments in syn-rift Oligocene- early Miocene; (3) Build-up play of Middle-early Miocene coral block, reef; (4) Play Pliocene- early Pleistocene turbidite.

In addition with the conventional hydrocarbon resources, the unconventional hydrocarbon resources such as gas hydrate are also the potential aspect and needed to concern for research. The main risk is the drilling and exploitation technology in the deep sea, high expenditure and investment cost. These Tertiary sedimentary basins in deepwater and marginal of Vietnam continental shelf are expected to have hydrocarbon potential and need to be investigated and explorated.

\section{Trang BO}




\section{Tiến hóa kiến tạo và tiềm năng dầu khí rìa thềm lục địa Việt Nam}

- Trần Như Huy

- Ngô Thường San

- Kiều Nguyên Bình

- Trần Văn Xuân

- Nguyễn Xuân Khá

- Nguyễn Xuân Huy

- Nguyễn Văn Tuân

Trường Đại học Bách Khoa, ĐHQG-HCM- tvxuan@hcmut.edu.vn

\section{TÓM TÁT:}

Kết quả khảo sát thời gian qua cho thấy ở rìa thềm lục địa Việt nam tồn tại các bể trầm tích Đệ tam có tiềm năng về dầu khí. Các bể này được thừa nhận hình thành vào đầu Oligocen trên móng lục địa có tuổi Mesozoi với các trầm tích lục nguyên tướng châu thổ. Vào đầu Miocen các bể được mở rộng, liên kết với tướng biển và châu thổ lấn tiến (prograding delta) phủ rộng khắp thềm lục địa. Từ Miocen trung đến hiện nay với sự mở rộng của Biển Đông, sự sụt lún khu vực và dao động mực nước đại dương đã tạo sự phát triển các trầm tích biển khơi và biển sâu với các tướng sét turbidit, đá vôi thềm xen với các thể san hô ám tiêu. Các thể andesit, basalt có thể được hình thành ở dạng các dyke và lớp phủ liên quan đến các hoạt động nghịch đảo kiến tạo vào cuối Oligocen, đầu Miocen giữa và đặc biệt vào cuối Miocen - Pliocen. Các bể trầm tích Đệ tam này được đánh giá có tiềm năng dầu khí và cần đượC nghiên cứu và tìm kiếm thăm dò. Rủi ro lớn nhất là công nghệ khoan và khai thác vùng biển sâu và vốn đầu tư lớn.

Từ Khóa: rìa thềm lục địa, tướng biển tiến, tướng biển thoái, hệ thống dầu khí, play tiềm năng, gas hydrate.

\section{TÀI LIỆU THAM KHẢO}

[1]. Metcalfe Ian, 2011, Tectonic framework and Phanerozoic evolution of Sundaland, Gondwana Research 19 (2011) 3-21;

[2]. Ngo Thuong San et al, 2007, Vietnam geology and petroleum resources, Monograph of
PetroVietnam;

[3]. Galloway, W. E., and Hobday, D. K., 1996, Terrigenous clastic depositional systems, Heidelberg, Springer-Verlag 